\title{
BIM adoption towards the sustainability of construction industry in Indonesia
}

\author{
Zhabrinna ${ }^{1,}$, Richard J. Davies ${ }^{1}$, M. Mirza Abdillah Pratama ${ }^{2}$, and Muhammad Yusuf ${ }^{3}$ \\ ${ }^{1}$ School of Engineering and Physical Science, University of Birmingham, Birmingham, United \\ Kingdom \\ ${ }^{2}$ Department of Civil Engineering, Faculty of Engineering, Universitas Negeri Malang, Malang, \\ Indonesia \\ ${ }^{3}$ School of Chemical and Process Engineering, University of Leeds, Leeds, United Kingdom
}

\begin{abstract}
The Architecture, Engineering and Construction (AEC) industry is known as one of the prominent sectors contributing to economic stability in Indonesia. On the other hand, this sector is also responsible for significant environmental impact in the country. Building Information Modelling (BIM) is a key innovative technology enabling advanced management within the construction and civil engineering industries and facilitating improvements in sustainability and asset management across the globe. BIM enables the achievement of three sustainable dimensions which are known as Triple Bottom Line (TBL). However, to enable the construction industry in Indonesia to expand and adopt this new engineering technology, the scarcity of the experts in BIM remains a barrier to initiate the migration from traditional management to BIM. From 40 respondents who participated in this study, only 2 respondents had competence in BIM. However, the awareness rate of Indonesian engineers about BIM is actually quite good with $67.5 \%$ of respondents having recognised BIM, although mostly with limited or basic knowledge. This research also defines BIM's impact to sustainability aspects in construction.
\end{abstract}

\section{Introduction}

According to the latest international financial research, Indonesia is one of the few developing countries in Asia with good economic stability [1] [2] [3]. To sustain the economic situation in Indonesia, the Architecture, Engineering and Construction (AEC) industry highly contributes as a prominent sector [4] [5]. Construction, as part of the AEC industry, provides infrastructure to boost national economic activities and provides employment for various skills and education graduates [4].

The development within the construction industry needs to focus on the maintenance of environmental sustainability. The construction industry is responsible for $30 \%$ of the global greenhouse gas (GHG) emission, $40 \%$ of global energy consumption, and $40 \%$ of all solid waste [6] [7] [8] [9]. The whole construction project life cycle - stages of building

*Corresponding author: zhabrinnas@gmail.com 
materials manufacture, construction, operation, and demolition - involve significant energy consumption and the generation of pollution. Other than the concern of environmental sustainability, the challenge for the construction industry to 'go green' is also enforced by the increasing energy cost, scarcity of resources, and regulations limiting GHG emission [7].

Building Information Modelling (BIM) is a transformative technology offering considerable benefits in the construction industry [10] [11]. BIM can be defined as a more integrated working platform which enables the collaboration of multidisciplinary information and interaction among stakeholders within one model [12] [13]. In Indonesia, most within the construction industry are still working with paper-based system, which takes a lot of time, effort, and resources to recognise clashes. In order to make the process faster and more organised, BIM can be used to address this problem. This shift from 'conventional' approach to BIM also supports the economic, social and environmental sustainability within the construction industry. The systematic and collaborative approach offered by BIM provides an opportunity to measure sustainability enhancement throughout a project's life cycle [14] [15].

\section{Literature review}

\subsection{BIM and the concept of sustainability}

BIM and sustainable construction have been receiving enormous attention in the AEC industry recently [16]. BIM facilitates innovation through providing an integrated working platform for the AEC industry from a project's inception, which results not only in technical benefits to the completion of project, but also an improvement in sustainability throughout the whole project's life cycle [12]. In contrast to the predominant paper-based systems within Indonesian AEC, BIM-enabled collaboration of all parties involved in the whole project's life cycle is facilitated by using this more sophisticated technology [16]. The 'Triple-Bottom-Line' (TBL) sustainability dimensions widely recognised are: social, economic, and environmental sustainability [17] [18]. A simultaneous integration of these three elements is needed to establish sustainability in a built environment effectively [13] and can be achieved through BIM [17].

Social sustainability can be defined as a situation that conforms to the necessity of people and their future generations [19]. In a built environment, social sustainability is achieved when stakeholders' needs are fulfilled [20]. In this case, BIM plays a role in providing a setting to promote better design to facilitate society's needs by enabling stakeholders to review and develop the 3D design, simulating its performance before the project is constructed in a collaborative working environment. This transition from a historically very fragmented process encourages all project stakeholders to share their viewpoints [21]. BIM-based systems have been also proposed in the form of integrated procurement systems [22] [13] strengthening social sustainability.

With regards to economic sustainability, BIM increases the saving of the life cycle cost in built facilities. A previous cost benefit analysis study conducted in a sample BIM project indicated a $6.92 \%$ saving of cost [23]. On the other hand, a recent research utilised an energy simulation system with BIM to analyse energy consumption and offer more information for design selection [24]. A recent study also explores a cost estimation system which is BIM-based to directly calculate the bill of quantities (BoQ) [25].

The principle in environmental sustainability includes alleviating the amount of GHG emissions to improve the quality of life [26]. BIM plays role in supporting a better spatial design, for instance in analysing potential environmental impacts, airflow circulation, a 
building's ecosystem, energy simulation and green assessment [27] [28]. There are already many studies and approaches that confirm that the use of BIM is able to bolster sustainability in the AEC industry. However, the discussion and exploration of this issue in Indonesia (with its own environmental climate context) are still considerably limited.

\subsection{Green BIM}

The rapid development of technology in the AEC industry such as the appearance of Computer Aided Design (CAD) era in the last decades creates an opportunity to transform traditional paper-based design formats and conventional project communication patterns. Moreover, the emergence of BIM takes the AEC industry to an even higher level of sophisticated technology. The strong collaboration and the richness of multidisciplinary information offered by BIM systems create an opportunity for sustainability enhancement.

'Green BIM' appears as a new omnipresent term which is considered to be a bridge between BIM and sustainability in the construction industry. With the growing popularity of the term 'Green BIM', there are several studies exploring this actual definition. The approaches in BIM practices in the construction industry consider Green BIM as a tool to achieve sustainability goals on a project [29]. Green BIM is also defined as the synergy of green buildings and BIM [30], and as a tool to support building designs to integrate sustainable components into a project's life cycle [31]. Some construction companies consider green BIM as a tool in order to generate a bigger impact on the construction project's efficiency and performance [13]. In summary, researchers propose the definition of 'Green BIM' as a model-based process in producing and managing building data to bolster the achievement of sustainability goals during a project's life cycle [7].

Utilising BIM in 'Green BIM' includes roles in effective and efficient design, modelling and analysis in digital format (e.g. to simulate the energy consumption, or solar impact). The advantages of data with high readability and the rich multidisciplinary information also benefits project communication. The advanced technology in BIM enables iterative modelling to achieve optimal design decisions which are environmentally friendly and also accomplishes high performance building attributes.

\section{Methodology}

This research focuses on the relation and the impact of BIM implementation to sustainability aspects in construction and building. A qualitive and quantitative questionnaire was used in order to collect data. In this research, 40 Indonesian practitioners in the construction industry were used as respondents in the quota sampling method [32]. A practitioner was defined as an engineer who is currently involved in building or infrastructure projects in Indonesia. The questionnaire was designed to identify how far the development of BIM adoption in Indonesia is, as well as to inquire on benefits gained by practitioners by implementing BIM, which are related to the sustainability aspect. In addition, closed and open questions were used for the questionnaire. Closed questions consisted of multiple choices and preference ratings, presented below in statistics. Meanwhile, open questions contained a discussion to explore the opinions and views of respondents.

\section{Result and discussion}

An online-based form was created to disseminate a structured questionnaire to collect information from Indonesian practitioners in the construction industry. 40 respondents from 
various engineering companies or organisations were involved in this study. From the feedbacks received, 23 respondents worked as contractors, 3 respondents worked as consultants, 6 were project owners, 6 worked in government, and 2 were architects.

The respondents are from various professional duties in their own company. Most of them are working as Engineers, Engineering Staff, and Site Engineers while the others identify their professional duty as Site Manager, Site Operation Manager, Engineering Manager, Quality Controller, Project Controller and Surveyor.

Since the term BIM is still new in Indonesia, this sought to measure how far the concept of BIM is understood in Indonesia. From asking respondents how they would describe their knowledge of BIM, $67.5 \%$ of the surveyed respondents have some understanding of BIM. However, only 2 respondents stated having competence in BIM, whereas the other 25 respondents describe their knowledge of BIM as limited or basic. The rate of respondents' awareness about BIM in this study is observed to be quite high, showing similar levels to the neighbouring country of Malaysia with $63 \%$ indicating awareness [33].

Respondents were surveyed to examine how the basic principles of BIM were currently being adopted within live projects. BIM is not only about technology, as BIM is prominently a process and platform to strengthen the integration of stakeholders involved in the project by improving communication and information management. The rationale of this second approach is to determine if Indonesian practitioners are actually familiar with the BIM concept, despite the lack of understanding about the definition of BIM.

There is an opportunity to observe several points through this approach, including the respondents' behaviour in project communication, data exchange, and project data storage. These points describe the basic principle of BIM which covers the integrated collaboration of stakeholders in project completion. The result shows that although the majority of respondents stated that they a have lack of knowledge of BIM, 55\% of respondents considered that their data storage system was already integrated, with project data put into one place to enable all parties involved to have appropriate access to the most recent updates. This behaviour indicated one of the components of implementation of basic BIM principles within a project. The remaining $45 \%$ of respondents indicated that their project data is individually stored. In the terms of communication and data exchange, email and face-to-face communication are the most preferable method for respondents. Other methods such as telephone calls and meetings are also conducted with a high frequency. On the other hand, the use of more sophisticated IT-based tools for project communication and data exchange is still considerably rare. This situation indicates that some concepts of BIM, in particular Information Management, are still not well understood.

In relation with the target to achieve sustainable construction in Indonesia, the respondents were asked their opinion about the benefits of BIM implementation towards the sustainability aspects within construction. This research used five (closed) statements offered in preference rating question-based [11] [16] [34] with additional open questions to facilitate deeper expression of the respondents point of views.

The Relative Index (RI) [35] of the respondents' response of closed questions was then calculated. The questionnaire disseminated adopts a five point ranking scale with 5 as the highest point to signify that the respondents strongly agree about the statement. RI is defined by this following formula:

$$
\text { Relative Index }(R I)=\frac{\Sigma P}{A x N}(0 \leq \text { index } \leq 1)
$$

In which:

$\mathrm{P}$ is the point given by the respondents to each statement provided.

The point is given between 1 to 5 , where 1 indicates that respondents strongly disagree and 5 indicate that respondents strongly agree with the statement; 
A is the highest point; and

$\mathrm{N}$ is the total number of respondents.

Table 1. The tabulation of respondents' response in RI calculation.

\begin{tabular}{|c|c|c|c|c|c|c|c|c|c|c|c|c|}
\hline Benefits of BIM & \multicolumn{2}{|c|}{$\begin{array}{l}\text { Strongly } \\
\text { disagree }\end{array}$} & \multicolumn{2}{|c|}{ Disagree } & \multicolumn{2}{|c|}{ Neutral } & \multicolumn{2}{|c|}{ Agree } & \multicolumn{2}{|c|}{$\begin{array}{c}\text { Strongly } \\
\text { agree }\end{array}$} & RI & Rank \\
\hline $\begin{array}{c}\text { Reduce } \\
\text { construction waste }\end{array}$ & 1 & $2.5 \%$ & 0 & $0 \%$ & 16 & $40 \%$ & 15 & $38 \%$ & 8 & $20 \%$ & 0.745 & 5 \\
\hline $\begin{array}{c}\text { Early detection of } \\
\text { conflict in design } \\
\text { and planning }\end{array}$ & 1 & $2.5 \%$ & 1 & $2.5 \%$ & 9 & $23 \%$ & 15 & $38 \%$ & 14 & $35 \%$ & 0.8 & 1 \\
\hline Reduce final cost & 1 & $2.5 \%$ & 1 & $2.5 \%$ & 10 & $25 \%$ & 19 & $48 \%$ & 9 & $22.5 \%$ & 0.77 & 4 \\
\hline Delay avoidance & 0 & $0 \%$ & 1 & $2.5 \%$ & 9 & $23 \%$ & 20 & $50 \%$ & 10 & $25 \%$ & 0.795 & 2 \\
\hline $\begin{array}{c}\text { Life asset } \\
\text { management } \\
\text { improvement }\end{array}$ & 0 & $0 \%$ & 1 & $2.5 \%$ & 10 & $25 \%$ & 19 & $48 \%$ & 10 & $25 \%$ & 0.79 & 3 \\
\hline
\end{tabular}

Table 1 presents the top five benefits of BIM implementation in the Indonesian construction industry and their ranking given by 40 practitioner respondents. The result indicates that Indonesian practitioners perceive all aspects presented to be of similar benefit. There is no polarisation between "short term" and "long term" benefits. The highest benefit achieved by the implementation of BIM is the early detection of conflict in design and planning, delay avoidance and life cycle asset management improvement. With a slightly lower RI: reducing final cost and reducing construction waste were considered. From the responses received in the open questions, the respondents inferred the clearer and more integrated project information in BIM to be advantageous in forewarning risks that may occur. BIM information is recognised as beneficial to plan preventive actions and avoid damages.

This indicates that the instant benefit received from applying BIM is considered to have slightly more impact for the respondents, rather than the longer-term benefits. Instant benefits such as clash detection and time scheduling bring immediate effects in the project. On the other hand, longer-term benefits such as reduction of both of total cost and construction waste, and life asset management improvement, can only be seen after the completion of the project. This result has a typical pattern with the other study conducted in Malaysia. The percentage of respondents who agreed or strongly agreed that BIM can improve the building design and shorten the project timescale have higher percentages, which are $65 \%$ and $54 \%$, rather than the percentage of the statement that BIM reduces project cost which is $51.5 \%$ [33]. However, by observing the result of Table 1, it can be seen that there is only a slight difference among the five elements' relative index. This indicates that all five benefits provided by BIM are considered important by the respondents, with only slight differences in priority or preference.

The respondents were also asked about the barriers to implement BIM in Indonesia. The result presented in Figure 1 shows that the dominant barrier to adopt BIM in Indonesia is perceived to be the lack of knowledge, followed by the lack of demand in the current construction industry market. Some other barriers identified are the matter of contract and law, high investment cost, and complex procedure. 


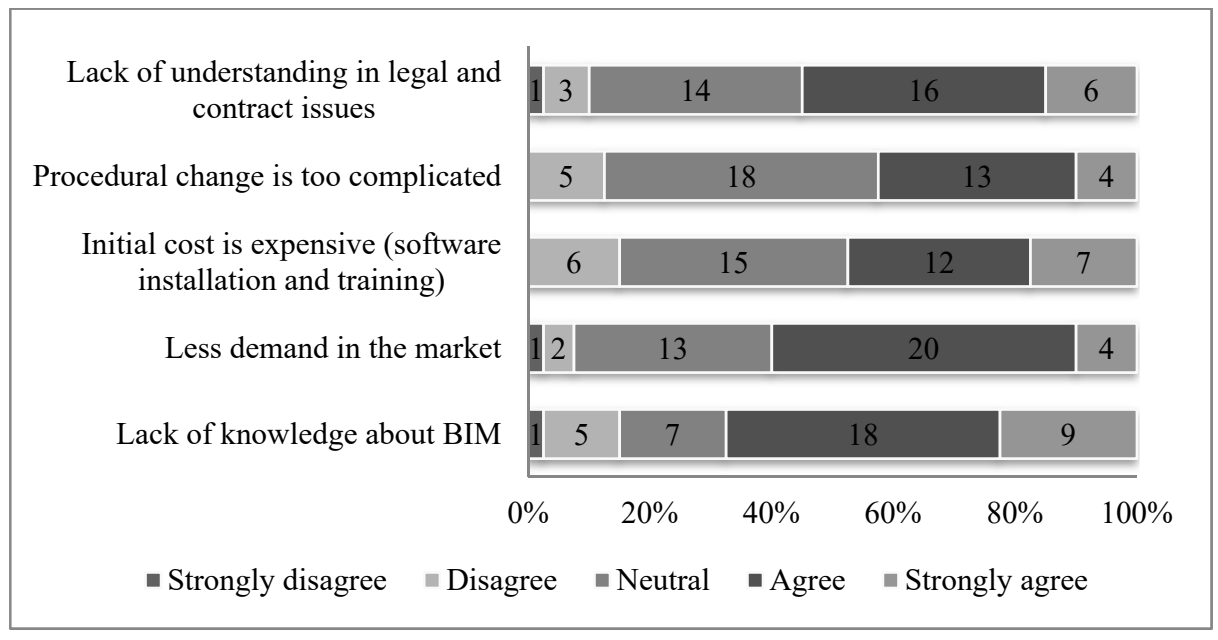

Fig. 1. Perceived barriers to BIM adoption in Indonesia.

\section{Conclusion}

This research describes how far the adoption of BIM has been progressing in Indonesia. The data shows that the number of engineers in Indonesia who have competence in using BIM is still low. However, the concept of BIM in integrated project data storage which enables the collaboration of stakeholders involved in information management is already applied by more than half of respondents.

The data and analysis indicate that most of the Indonesian practitioners who responded confirm that the implementation of BIM within projects improves sustainability within the construction industry. The early detection of clashes reduces potential errors during work, reduces the need to "fix issues on site" and reduces construction waste. Additional benefits arise from this as diminishes the probability of delays and cost overrun due to rework, and the additional work costs of delays themselves add to the project final cost. The implementation of BIM is seen to reduce the final cost and avert delays which impact economical sustainability. Recent studies and experiences confirm that BIM also enables improvement in asset lifecycle management by improving the environmental, economic and also social aspects of sustainability.

It can also be concluded from Table 1 that the respondents recognise the advantages gained in the construction phase of a project's life cycle with BIM implementation, and also the larger longer-term benefits to the completed asset within the operation and maintenance stage. Despite the current low awareness of BIM indicated within Indonesia, respondents recognised that there are considerable benefits to be gained by BIM implementation.

Given the generally recognised value of BIM, it is recommended that Indonesia should look to focus its efforts on education of BIM in order to promote this transition; this would also increase the number of Indonesian BIM practitioners in the AEC industry. Alongside this increased dissemination of BIM knowledge, promoting the awareness of sustainability in built environment is recommended. This study also notes that the act of asking questions with regards to BIM also served to raise the awareness of the respondents, and it is further recommended that the conferment of questions in questionnaires should then be followed by educational activities. Further studies in the future are recommended to elaborate more on the identification and promotion of sustainability benefits, especially the direct environmental impacts, by the implementation of BIM in the projects within the Indonesian context. 


\section{References}

1. IMF Asia and Pacific Dept, "Indonesia: 2017 Article IV Consultation-Press Release; Staff Report; and Statement by the Executive Director for Indonesia," (2018).

2. A. Kurniawan. Stabilitas Ekonomi Indonesia Diakui Lembaga Internasional. [Online]. https://ekbis.sindonews.com/read/1189293/33/stabilitas-ekonomi-indonesia-diakuilembaga-internasional-1489746503 (2017, March)

3. S.R.D. Setiawan. IMF: Indonesia Berhasil Jaga Stabilitas Ekonomi. [Online]. http://ekonomi.kompas.com/read/2017/02/04/180000426/imf.indonesia.berhasil.jaga.st abilitas.ekonomi (2017, February)

4. R.D. Wirahadikusumah, K.S. Pribadi, "Licensing construction workforce: Indonesia's effort on improving the quality of national construction industry," Engineering, Construction and Architectural Management, vol. 18, no. 5, pp. 431-443, 2011.

5. The Big 5 Construct Indonesia, "Pesatnya Pertumbuhan Pasar Konstruksi Dan Bangunan Indonesia Menuntut Adanya Ajang Penyedia Berbagai Produk Lokal Maupun Internasional," Jakarta. [Online].

https://www.konstruksiindonesiabig5.com/media/1476/big-5-indonesia-bahasamarch.pdf (2015)

6. Change Intergovernmental Panel on Climate, "Climate Change 2001: Mitigation," Cambridge, (2001).

7. J.K.W. Wong, J. Zhou, "Enhancing environmental sustainability over building life cycles through green BIM: A review," Automation in Construction, vol. 57, pp. 156165, (2015).

8. J. Teng, X. Wu, "Eco-footprint-based life-cycle eco-efficiency assessment of building projects," Ecological Indicators, vol. 39, pp. 160-168, (2014).

9. United Nations Environment Programme, "Assessment of policy instruments for reducing greenhouse gas emissions from buildings," United Nations Environment Programme, Budapest, (2007).

10. P. Saieg, E.D. Sotelino, D. Nascimento, R.G. Caiado, "Interactions of Building Information Modeling, Lean and Sustainability on the Architectural, Engineering and Construction industry: A systematic review," Journal of Cleaner Production, pp. 788806, (2018).

11. Zhabrinna, "The Evaluation of the Readiness of Indonesia in Adopting BIM and the Strategic Improvement by Benchmarking the Best Practice of BIM Implementation in the UK," MSc. Thesis The University of Birmingham, Birmingham, (2017).

12. A. Gilder, J. Elmualim, "BIM: innovation in design management, influence and challenges of implementation," Architect Engineering Design Management, vol. 10, pp. 183-199, (2014).

13. H.Y. Chong, C.Y. Lee, and X. Wang, "A mixed review of the adoption of Building Information Modelling (BIM) for sustainability," Journal of Cleaner Production, vol. 142, pp. 4114-4126, (2017).

14. Autodesk, "Improving Building Industry Results Through Integrated Project Delivery and BIM," (2008).

15. S. Azhar, J. Brown, A. Sattineni, "A case study of building performance analyses using building information modeling," in Proceedings of the 27th International Symposium on Automation and Robotics in Construction, Bratislava, (2010). 
16. C. Eastman, P. Teicholz, R. Sacks, K. Liston, BIM Handbook: a Guide to Building Information Modeling for Owners, Managers, Designers, Engineers and Contractors. New York: John Wiley \& Sons, (2011).

17. E.A. Khan, M.N.A. Dewan, M.M.H. Chowdhery, "Reflective or formative measurement model of sustainability factor? A three industry comparison," Corp. Ownersh. Control, pp. 83-92, (2016).

18. M.L. Martens, M.M. Carvalho, "Key factors of sustainability in project management context: A survey exploring the project managers' perspective," International Journal of Project Management, pp. 1084-1102, (2017).

19. M.P. Eastaway, "Social sustainability," in Encyclopaedia of Housing and Home Woodstock. USA: Elsevier, 2012, pp. 501-505.

20. E. Almahmoud, H.K. Doloi, "Assessment of social sustainability in construction projects using social network analysis," Facilities, pp. 152-176, (2015).

21. NIBS, "National BIM Standard-United States ${ }^{\circledR} \quad\left(\right.$ NBIMS-us ${ }^{\mathrm{TM}}$ ) Version 3," Washington, (2015).

22. A. Grilo, R.J. Goncalves, "Challenging electronic procurement in the AEC sector: a BIM-based integrated perspective," Auto. Constr., pp. 107-114, (2011).

23. W. Lu, et al., "Cost-benefit analysis of Building Information Modelling implementation in building projects through demystification of time-effort distribution curves," Build. Environ., pp. 317-327, (2014).

24. S.J. Guo, T. Wei, "Cost-effective energy saving measures based on BIM technology: case study at National taiwan university," Energy \& Build, no. 127, pp. 433-441.

25. E. Plebankiewicz, K. Zima, M. Skibniewski, "Analysis of the first Polish BIM-Based cost estimation application," Procedia Eng., pp. 405-414, (2015).

26. P. Sassi, "Built environment sustainability and quality of life (BESQoL) assessment methodology," in Engaging Stakeholders in Education for Sustainable Development at University Level, World Sustainability Series. Switzerland: Springer International Publishing, (2016).

27. W. Bonenberg, W. Xia, "Green BIM in sustainable infrastructure," Procedia Manuf., pp. 1654-1659, (2015).

28. S.G. Al-Ghamdi, M.M. Bilec, "Life-cycle thinking and the LEED rating system: global perspective on building energy use and environmental impacts," Environ. Sci. Technology, pp. 4048-4056, (2015).

29. McGraw-Hill Construction, "Green BIM: How Building Information Modelling is Contributing to Green Design and Construction," (2010).

30. W. Wu, R. Issa, "BIM Execution Planning in Green Building Projects: LEED as a Use Case," J. Manage. Eng., (2015).

31. A. Alawini, et al., "Technology adoption: building IT," in Research and Technology Management in the Electricity Industry: Methods, Tools and Case Studies., (2013).

32. C. A. Moser, "Quota Sampling," Journal of the Royal Statistical Society, vol. 115, no. 3, pp. 411-423, (1952).

33. J.P. Rogers, "The Strategic Adoption of Building Information Modelling by Malaysian Engineering Consulting Services Firms," Lismore, (2013).

34. R. Eadie, et al., "BIM implementation throughout the UK construction project lifecycle: An analysis," Automation in Construction, pp. 145-151, (2013).

35. A. Field, Discovering statistics using SPSS, 3rd ed. London: Sage publications, (2009). 